\title{
Speciation of dissolved copper within an active hydrothermal edifice on the Lucky Strike vent field (MAR, $37^{\circ} \mathrm{N}$ )
}

\author{
Pierre-Marie Sarradin ${ }^{a}{ }^{*}$, Matthieu Waeles ${ }^{b}$, Solène Bernagout ${ }^{a}$, Christian Le Gall $^{\mathrm{a}}$, Jozée \\ Sarrazin $^{\mathrm{a}}$ and Ricardo Riso ${ }^{\mathrm{b}}$
}

\footnotetext{
a Ifremer centre de Brest, Département Etudes des Ecosystèmes Profonds, BP70, F-29280 Plouzané, France

${ }^{\mathrm{b}}$ Laboratoire de Chimie Marine, UBO et UMR CNRS 7144, Place Nicolas Copernic, F-29280 Plouzané, France

*: Corresponding author : Pierre-Marie Sarradin' email address : Pierre.Marie.Sarradin@ifremer.fr
}

\begin{abstract}
:
The objective of this study was to determine the concentrations of different fractions of dissolved copper (after filtration at $0.45 \mu \mathrm{m}$ ) along the cold part of the hydrothermal fluid-seawater mixing zone on the Tour Eiffel edifice (MAR). Dissolved copper was analyzed by stripping chronopotentiometry (SCP) after chromatographic C18 extraction. Levels of total dissolved copper (0.03 to $5.15 \mu \mathrm{M})$ are much higher than those reported for deep-sea oceanic waters but in accordance with data previously obtained in this area. Speciation measurements show that the hydrophobic organic fraction $(\mathrm{C} 18 \mathrm{Cu})$ is very low $(2 \pm 1 \%)$. Dissolved copper is present mainly as inorganic and hydrophilic organic complexes (nonC18Cu). The distribution of copper along the $\mathrm{pH}$ gradient shows the same pattern for each fraction. Copper concentrations increase from $\mathrm{pH} 5.6$ to 6.5 and then remain relatively constant at $\mathrm{pH}$ $>$ 6.5. Concentrations of oxygen and total sulphides demonstrate that the copper anomaly corresponds to the transition between suboxic and oxic waters. The increase of dissolved copper should correspond to the oxidative redissolution of copper sulphide particles formed in the vicinity of the fluid exit. The presence of such a secondary dissolved copper source, associated with the accumulation of metal sulphide particles, could play a significant role in the distribution of fauna in the different habitats available at vents.
\end{abstract}

Keywords: Dissolved copper; Speciation; Hydrothermal vent; Mid Atlantic Ridge 


\section{Introduction}

The circulation of seawater through fractured rocks at mid oceanic ridges produces important exchanges between lithosphere and hydrosphere. The resulting hydrothermal vents provide hot, reduced and acidic fluids which contain high amounts of various mineral compounds, including hydrogen sulphide, methane, carbon dioxide and many metals such as iron, manganese and copper, (Von Damm et al., 1998; Charlou et al., 2000; Douville et al., 2002). The peculiar and highly productive dense fauna encountered close to hydrothermal vents is not dependant on photosynthesis but rely on microbial chemosynthetic primary producers using reduced chemicals present in the hydrothermal fluid (Childress and Fisher, 1992). Hydrothermal vent fauna is periodically bathed within a variable mixture of hydrothermal fluid and seawater. This environment is chemically highly reactive with the coexistence of oxidized and reduced chemical species (Luther et al., 2001). Steep temperature and chemical gradients are encountered produced by the turbulent mixing of the hot fluid and the cold seawater (Le Bris et al., 2006). The hydrothermal fluid provides to the vent fauna at the same time the necessary energy sources such as methane and hydrogen sulphide (Urcuyo et al., 2003), but also potential stressors or "toxic" compounds such as heavy metals (Douville et al., 2002; Sarradin et al., 2008), high temperature (Shillito et al., in press) or radionuclides. The understanding of the chemical and biological processes controlling the composition of this mixing zone is a necessary step in the study of the functioning of the whole ecosystem (Sarrazin et al., 2006b). The study of trace metals along the hydrothermal fluid-seawater mixing zone is of highly importance because some of these elements and particularly copper can be both essential and toxic for many biological species (Cosson and Vivier, 1997). Mytilids mussels, as well as clams and vestimentiferan tube worms, living in the vent environment accumulate large amounts of metals with surprisingly no evident deleterious 
effects (Geret et al. 1998, Ruelas-Inzunza et al. 2003 and 2005, Cosson and Vivier 1997,

60 Cosson et al., 2008). To cope with their harmful environment, they have developed efficient mechanisms against the toxicity of heavy metals including their intracellular sequestration as non toxic granules, or the production of metallothioneins and antioxidants (Cosson and Vivier, 1997; Bebianno et al., 2005).

Studies exploring the behaviours of metals after their emission in the hydrothermal fluid were mainly focussed on the plume (Trefry and Trocine, 1985; Feely et al., 1990 and 1994; James and Elderfield, 1996). A few authors have started to describe the characteristics of total metal concentrations in the habitats of the hydrothermal fauna (Sarradin et al., 1999; Desbruyères et al., 2001; Geret et al., 2002; Di Meo-Savoie et al., 2004). The main observations arising from these papers presenting concentrations of total metals are the enrichment of this part of the mixing zone accounting for the hydrothermal input and the large variability in the obtained data. However, studies on speciation are necessary to improve our knowledge on metal behaviour and availability in hydrothermal environments. First trials were done on a $2-\mu \mathrm{m}$ fractionation for $\mathrm{Cu}, \mathrm{Zn}, \mathrm{Cd}$ and $\mathrm{Pb}$ in hydrothermal water samples from the EPR (Sarradin et al., 2008). In particular, the results showed that particulate $(>2 \mu \mathrm{m})$ and dissolved $(<2 \mu \mathrm{m})$ $\mathrm{Cu}$ were not following a conservative behaviour during the mixing of hydrothermal fluid and seawater.

In natural waters, copper coexists under different chemical species such as free hydrated cations $\left[\mathrm{Cu}\left(\mathrm{H}_{2} \mathrm{O}\right)_{6}\right]^{2+}$, as well as inorganic complexes $\left(\mathrm{CuOH}^{-}, \mathrm{CuCO}_{3} \ldots\right)$ and organic complexes (CuL). Recently, Sander et al. (2007) reported for the first time the important role of organic ligands to control the copper speciation in hydrothermal systems. However, the exact nature and evolution of the various copper species along the hydrothermal fluidseawater mixing zone are still unknown. 
The study reported here was carried out in the Tour Eiffel hydrothermal edifice located on the Lucky Strike field on the Mid Atlantic Ridge. Dissolved copper (not retained on a $0.45 \mu \mathrm{m}$ filter) was analyzed by stripping chronopotentiometry (SCP) after solid-liquid chromatographic $\mathrm{C}_{18}$ extraction (Mills and Quinn, 1981). From this extraction, two fractions are obtained: (i) the non-polar hydrophobic organic one $\left(\mathrm{C}_{18} \mathrm{Cu}\right)$ is a subset of the organicallycomplexed pool and may greatly affect the metal bioavailability (Elbaz-Poulichet et al., 1994); (ii) the second fraction consists of inorganic and hydrophilic organic complexes (nonC ${ }_{18} \mathrm{Cu}$ ). It is worth noting that the $\mathrm{C}_{18}$ method has been extensively used for studies on estuarine, coastal and oceanic waters (e.g. Mills and Quinn, 1981; Paulson et al., 1994; ElbazPoulichet et al., 1994; Yoon et al., 1999; El Sayed and Aminot, 2000; Waeles et al., 2004 and 2005) but has never been implemented for hydrothermal systems. Our aim was thus to determine the concentrations of not retained copper and of its various species on an active hydrothermal edifice and also to investigate their changes along the cold part of the hydrothermal fluid-seawater mixing zone.

\section{Material and methods}

\section{1 study area}

This study was conducted during the MoMARETO cruise (Sarrazin et al., 2006) held on the French oceanographic vessel "Pourquoi pas?" with the ROV Victor 6000 in 2006. It focussed on the active hydrothermal edifice Tour Eiffel within the Lucky Strike vent field $\left(37^{\circ} 17,29^{\prime} \mathrm{N}, 32^{\circ} 16,45^{\prime} \mathrm{W}\right)$ on the Mid Atlantic Ridge (Figure 1). Lucky Strike is one of the largest known active hydrothermal vent fields. The vent sites are distributed around a large lava lake at depths varying from 1650 to $1750 \mathrm{~m}$ (Fouquet et al., 1995). Faunal communities are dominated by extensive mussel beds of Bathymodiolus azoricus partially covered by visible microbial mats. The vicinity of active high-temperature chimneys, flanges and cracks 
are colonized by shrimp assemblages (Desbruyères et al., 2001). On the Tour Eiffel edifice, 4

109 or 5 chimneys are venting a hot fluid with a temperature of up to $325^{\circ} \mathrm{C}$, concentrations of $\mathrm{Fe}$ ranging from 595 to $704 \mu \mathrm{M}$ and $\mathrm{H}_{2} \mathrm{~S}$ concentrations of 2100-2500 $\mu \mathrm{M}$ (Charlou et al., 2000).

111 Twelve sampling units were chosen on different sides and at different altitudes on the 11-m

112 tall sulphide edifice in order to have a representative overview of the chemical conditions 113 over the faunal assemblages (Figure 2).

\subsection{Sampling and sample treatment}

116 Forty two water samples were collected on the 12 sampling units (2-5 samples per station;

117 Figure 2) using the "PEPITO" sampler of the ROV Victor 6000. PEPITO is a new water

118 sampling device qualified up to $6000 \mathrm{~m}$ depth (Sarradin et al., 2007). It can collect up to 23

119 water samples in $200 \mathrm{~mL}$ titanium/PEEK bottles. All the materials used for the transfer or

120 storage of the samples are chemically inert (PEEK, Titanium, Viton). The manifold is

121 designed to minimize contamination between samples with very low dead volumes. The

122 samples were pumped using a titanium-Tygon inlet associated to the ROV temperature probe.

123 Immediately after the recovery of the ROV, the sampling bottles were carried out to the

124 chemical lab of the oceanographic vessel (clean lab, P 100 000; ISO8). pH measurements

125 were performed on a subsample using a Metrohm ${ }^{\circledR} \mathrm{pH}$-meter with a combined $\mathrm{pH}$ electrode

126 (Ingold $®$ ) for sulphide rich medium (precision \pm 0.01 ). Measurements were made at $25^{\circ} \mathrm{C}$

127 after calibration with NBS buffers ( $\mathrm{pH} 4$ and 7). Sample temperatures were derived from the

128 data recorded by the temperature probe associated with the sample inlet. The seawater

129 samples were passed through a $0.45-\mu \mathrm{m}$-Millipore ${ }^{\circ}-\mathrm{HATF}$ filter. Dissolved copper in this

130 paper is the operationally (by filter pore size) defined fraction $<0.45 \mu \mathrm{m}$. A 50 -mL aliquot of

131 the filtrate was acidified at $\mathrm{pH}$ 2, then stored in Nalgene HDPE bottles at ambient temperature

132 until further analysis of the total dissolved copper (TDCu). Another $100 \mathrm{~mL}$ aliquot, 
maintained at seawater $\mathrm{pH}$, was stored at $-20^{\circ} \mathrm{C}$ in Nalgene HDPE bottles. The separation and

134 the quantification of the hydrophobic organic copper complexes $\left(\mathrm{C}_{18} \mathrm{Cu}\right)$, and the inorganic 135 and hydrophilic organic complexes $\left(\right.$ nonC $\left._{18} \mathrm{Cu}\right)$ were performed on shore.

136 Filtrations, $\mathrm{C}_{18}$ extractions and analyses were carried out in class-100 laminar flow hood-

137 equipped laboratories. Prior to use, all the items employed for sampling, filtration and storage

138 were washed several times with diluted hydrochloric acid ( $\mathrm{pH} 2, \mathrm{HCl}$ suprapur®, Merck) and

139 then rinsed with Milli-Q RG® water. The filters were soaked in diluted hydrochloric acid (pH

140 2) for 2 month before the cruise.

141 At each sampling site, in-situ measurements of total sulphide were realized using a new

142 chemical analyzer described in Vuillemin et al. (2007 and submitted). The concentrations of

143 dissolved oxygen and temperature were recorded using an autonomous Optode Aanderaa 1443830 (Tengberg et al., 2006).

\subsection{Separation and analyses of the various copper chemical species}

147 Because conventional $\mathrm{C}_{18}$ silica columns are subjected to polar interactions associated with

148 the surface free silanol groups, endcapped $\mathrm{C}_{18}$ columns recently developed by Interchrom ${ }^{\circledR}$

149 ( $\mathrm{C}_{18}$-S-200LRC) for solid-liquid chromatography were selected in order to obtain the non-

150 polar organic fraction with a better accuracy. The protocol used was the one described by

151 Mills and Quinn (1981). The $\mathrm{C}_{18}$ column was first washed by passing successively $10 \mathrm{~mL}$ of

152 methanol (G Chromasolv ${ }^{\circledR}$, Sigma-Aldrich), $10 \mathrm{~mL}$ of $\mathrm{HCl} 3.10^{-2} \mathrm{M}$ (Suprapur ${ }^{\circledR}$, Merck),

$15310 \mathrm{~mL}$ of methanol and finally $20 \mathrm{~mL}$ of Milli-Q water. Then, $30 \mathrm{~mL}$ of the sample were

154 percolated through the column at a flow rate of $10 \mathrm{~mL} \mathrm{~min}^{-1}$. Elution was achieved by passing

$1556 \mathrm{~mL}$ of a methanol/Milli Q water mixture (v/v 1:1). The resulting eluate was completed to

$15630 \mathrm{~mL}$ with acidified water at $\mathrm{pH}$ 2. The eluted fraction contained the $\mathrm{C}_{18} \mathrm{Cu}$ species, i.e. the

$157 \mathrm{Cu}$ complexed with non polar hydrophobic ligands which includes colloidal $\mathrm{Cu}$ ( Paulson et 
al. 1994). The nonC ${ }_{18} \mathrm{Cu}$ species were in the unretained fraction and consist of inorganic

159 copper $\left(\mathrm{eg} \mathrm{Cu}^{2+}, \mathrm{CuOH}^{-}, \mathrm{CuCO}_{3} \ldots\right)$ and $\mathrm{Cu}$ associated with some non colloidal hydrophilic

160 organic complexes.

161 Recovery tests of the endcapped columns have been conducted on a coastal seawater sample

$162(\mathrm{n}=5)$. The results gave a recovery of $101 \pm 12 \% .26 \pm 5 \%$ of copper was retained on the $\mathrm{C}_{18}$

163 column whereas $75 \pm 7 \%$ of copper was not retained. Column blanks were prepared by passing

$164100 \mathrm{~mL}$ Milli- $\mathrm{Q}^{\circledR}$ water on the $\mathrm{C}_{18}$ column under the same conditions as for samples. The

165 results obtained for the $\mathrm{C}_{18} \mathrm{Cu}$ and the nonC ${ }_{18} \mathrm{Cu}$ fractions were $0.24 \pm 0.16 \mathrm{nM}(\mathrm{n}=3)$ and

$1660.20 \pm 0.11 \mathrm{nM}(\mathrm{n}=3)$, respectively. In addition, the concentration of dissolved copper in $\mathrm{pH}$

167 2-acidified Milli- $\mathrm{Q}^{\circledR}$ water was $0.17 \pm 0.10 \mathrm{nM}(\mathrm{n}=3)$. Comparison with this "reference"

168 value showed that the blank ones fell in the same range; thus, no additional contamination

169 was observed from the $\mathrm{C}_{18}$ extraction. Extraction reproducibility was assessed on a coastal

170 seawater sample. Under the same conditions the $\mathrm{C}_{18} \mathrm{Cu}$ forms account for $26 \pm 5 \%(\mathrm{n}=5)$ and

171 the nonC ${ }_{18} \mathrm{Cu}$ forms account for $75 \pm 7 \%(\mathrm{n}=5)$.

172 The various copper species $\left(\mathrm{TDCu}, \mathrm{C}_{18} \mathrm{Cu}\right.$ and $\left.\mathrm{nonC}_{18} \mathrm{Cu}\right)$ were measured by stripping

173 chronopotentiometry (SCP) with a gold electrode using the standard method. This method

174 was developed in the lab (Riso et al., 1997a) and has been commonly used in estuarine and

175 coastal waters (Waeles et al., 2004 and 2005). This method is very appropriate for total

176 dissolved copper quantification in organic matter-rich seawater samples since it requires no

177 preatreatment by UV irradiation. The reproducibility is $2 \%$ and the detection limit $0.17 \mathrm{nM}$

178 (Riso et al., 1997a and 1997b). The results obtained for the analysis of copper in certified

179 seawater samples are presented in Table 1.

180

181 3. Results and discussion

182

3.1 Temperature, $\mathrm{pH}$ and total dissolved copper 
183 The complete data set is presented in appendix 1. Temperature and $\mathrm{pH}$ levels in the 43 184 samples are in the range of 4.6 to $22^{\circ} \mathrm{C}$ and 5.4 to 7.5 respectively. These values are 185 characteristic of the cold part of the mixing zone between the hydrothermal fluid $\left[\mathrm{T}=324^{\circ} \mathrm{C}\right.$, pH $3.5-4.2$ (Charlou et al., 2000)] and seawater $\left(\mathrm{T}=4.4^{\circ} \mathrm{C}, \mathrm{pH} 7.8\right)$. The corresponding hydrothermal input can be roughly estimated using the temperature endmember data (Von 188 Damm et al., 1998; Charlou et al., 2000). The calculated fluid input (fluid input \% $=0.314 \mathrm{~T}$ 1891.38 ) is limited to 0.1 to $5.5 \%$. The possibility of using temperature or $\mathrm{pH}$ as dilution tracer of hydrothermal fluid by seawater was tested using the $\mathrm{T} / \mathrm{pH}$ relationship of our samples. The sigmoid trend obtained (Figure 3) can explain $86 \%$ of the variability in the data. This result

192 confirms that at the scale and in the range studied, $\mathrm{pH}$ and temperature can be assumed to 193 follow a semi-conservative process and can be used as tracers of the dilution. In this paper, $194 \mathrm{pH}$ is used preferentially as dilution tracer rather than temperature because it was measured directly in the samples whereas temperature was derived from sensor data.

196 The total dissolved copper concentrations (TDCu) vary between 0.03 and $5.15 \mu \mathrm{M}$ in the 197 samples $(n=42)$. These values are clearly far greater (one to three orders of magnitude) than 198 the ones reported for deep North Atlantic waters, i.e. 1.0 to $3.2 \mathrm{nM}$ (Bruland and Franks, 199 1983; Donat and Bruland, 1995; Saager et al., 1997; Le Gall et al., 1999), indicating a marked copper enrichment due to hydrothermal inputs. These concentrations are also lower than the 20-34 $\mu \mathrm{M}$ of total copper estimated by Von Damm et al. (1998), Charlou et al. (2000) and Douville et al. (2002) in the Tour Eiffel endmember fluid. Our copper concentrations fall 203 within the range of the ones reported for the same area or for other hydrothermal systems 204 colonized by vent fauna (Table 2) and they are in accordance with the ones previously 205 reported by Geret et al. (1998) for the Tour Eiffel site. Surprisingly, the ranges are 206 comparable to the concentrations found in other hydrothermal systems characterized by 207 different geographical (EPR and MAR) and geological settings (Rainbow and Lucky Strike) 
with likely differences in the chemical composition and the biogeochemistry of the mixing

zones. However, the concentrations previously published represent the concentration found in unfiltered samples. Finally, the variability observed is important with concentrations of total dissolved copper spreading between 0.03 to $5.15 \mu \mathrm{M}$ in a $17^{\circ} \mathrm{C}$ temperature and $2 \mathrm{pH}$ units 212 gradient.

\subsection{Dissolved copper species concentrations}

Inorganic and hydrophilic organic copper concentrations (nonC ${ }_{18} \mathrm{Cu}$ ) range between 0.020 and $4.85 \mu \mathrm{M}$ whereas hydrophobic organic copper levels $\left(\mathrm{C}_{18} \mathrm{Cu}\right)$ vary from 0.001 to $0.095 \mu \mathrm{M}$. Thus, copper on the Tour Eiffel edifice occurs mainly as inorganic or hydrophilic organic species whereas the $\mathrm{C}_{18} \mathrm{Cu}$ fraction appears to be very low. This fraction, which was measured for the first time in a hydrothermal environment, accounts only for $2 \pm 1 \%$ of the total dissolved copper $(n=42)$.

Compared to other marine environments, lower ratios of $\mathrm{C}_{18} \mathrm{Cu} / \mathrm{TDCu}$ are obtained in this hydrothermal system. As examples, in the North Atlantic and the North Pacific oceans, hydrophobic organic complexes may represent 11 to $36 \%$ of the total dissolved copper (Hanson and Quinn, 1983; Donat et al., 1986- filtration on $0.3 \mu \mathrm{m}$ ). In Mediterranean waters filtered on $0.4 \mu \mathrm{m}$, the $\mathrm{C}_{18} \mathrm{Cu} / \mathrm{TDCu}$ ratios were in the range of 11 to $55 \%$ (Elbaz-Poulichet et al., 1994; Yoon et al., 1999). Studies conducted in estuarine systems and coastal waters report slightly higher ratios compared to oceanic waters with values ranging from 11 to $66 \%$ 228 (Waeles et al., 2004- filtration on $0.45 \mu \mathrm{m}$ ).

229 The particularly low ratios obtained for our study may ensue from two complementary causes 230 or origins. Firstly, our experiments were conducted with endcapped $\mathrm{C}_{18}$ columns whereas the 231 previously cited studies used non-endcapped ones (Hanson and Quinn, 1983; Donat et al., 232 1986; Elbaz-Poulichet et al., 1994; Yoon et al., 1999). The latter type of columns is 
susceptible to retain the non-polar hydrophobic forms, but also a part of the polar compounds

234 as well. The overestimation of the non-polar hydrophobic fraction by non-endcapped columns 235 has been assessed on a coastal seawater sample prior to this study and has been also evaluated 236 by El Sayed and Aminot (2000) on samples of Mediterranean water. From our measurements, 237 the $\mathrm{C}_{18}$ fraction retained by non-endcapped columns $(52 \pm 7 \%)$ is twice higher that the one 238 retained by endcapped columns $(26 \pm 5 \%)$. By using a Chelex-100 resin pre-treatment before 239 the $\mathrm{C}_{18}$ extraction, El Sayed and Aminot (2000) found a $\mathrm{C}_{18} \mathrm{Cu} / \mathrm{TDCu}$ ratio of $6.6 \pm 0.4 \%$ 240 whereas a 3 -fold ratio $(21.8 \pm 1.7 \%)$ was reported after extraction when using only the non241 endcapped $\mathrm{C}_{18}$ columns.

242 Secondly, the low hydrophobic organic copper complexation observed in hydrothermal 243 waters can be cross-checked with the results of Sander et al. (2007). Over their study on three 244 different vent fields, they found that $11 \%$ of copper or more should be complexed by organic matter. By comparison, estimations in estuarine and coastal media indicated that more than 99\% of copper is organically complexed (Donat et al., 1994). Organic ligands can have different origins in the hydrothermal environment studied. For example, Holms and Charlou, 248 (2001) observed the abiotic production of linear saturated hydrocarbons (C16-C29) during the 249 hydrothermal process in ultramafic systems. A potentially important source will be the complex detritic organic matter produced by hydrothermal faunal assemblages (Limen et al., 2001). Finally, the production of microbial exopolysaccharides have been revealed in deep sea vents (Nichols et al., 2005). These extracellular polymers have been shown to possess 253 strong metal chelating properties (Loaec et al. 1998). Indeed, in hydrothermal systems, 254 sulphides which form stable complexes with copper $\left[\mathrm{K}^{\prime}(\mathrm{CuL})=11.5\right.$ (Al-Farawati and van den Berg, 1999)] may be present at concentrations 250-fold higher than that of copper organic 256 ligands. Such high sulphide levels should limit the formation of organic complexes and 257 particularly of non-polar hydrophobic ones even though other metals such as Fe or Zn, which 
have higher concentrations than $\mathrm{Cu}$ in hydrothermal fluids, can also compete for sulphide as 259 potential ligands. Al-Farawati and van den Berg (1999) determined the stability constant of 260 metal sulphides complexes in pH 8 seawater. In the presence of organic ligands, the copper 261 organic species are dominant for sulphide $<1 \mathrm{nM}$ (i.e. $\mathrm{Cu}<$ sulphide). At higher levels of 262 sulphide, copper monobisulphide $\left(\mathrm{CuHS}^{+}\right)$and copper dibisulphide $\left[\mathrm{Cu}(\mathrm{HS})_{2}\right]$ will constitute 263 the major species. In this study, the total sulphide concentration was measured in situ and 264 ranges between 0.1 to $69 \mu \mathrm{M}$. The resulting ratio $\mathrm{H}_{2} \mathrm{~S}_{\mathrm{T}} / \mathrm{TDCu}$ varies from 1.8 at $\mathrm{pH} 7$ to 400 265 at $\mathrm{pH} 5.7\left(\mathrm{H}_{2} \mathrm{~S}_{\mathrm{T}}=40 \mu \mathrm{M}, \mathrm{TDCu}=0.1 \mu \mathrm{M}\right)$. The measured values are always in the case of a $\mathrm{H}_{2} \mathrm{~S}_{\mathrm{T}} / \mathrm{Cu}>1$ favouring the formation of inorganic sulphide complex (copper mono bisulphide and copper dibisulphide) rather than organic complexes according to the laboratory work done by Al-Farawati and van den Berg (1999).

\subsection{Copper behaviour in the hydrothermal fluid-seawater mixing zone}

271 Figure 4 depicts the variations of $\mathrm{TDCu}, \mathrm{C}_{18} \mathrm{Cu}$ and nonC ${ }_{18} \mathrm{Cu}$ concentrations versus $\mathrm{pH}$. The

$272 \mathrm{pH}$ decrease indicates an increase of the hydrothermal input. TDCu levels increase from 33 to 273 approximately $1000 \mathrm{nM}$ for a $\mathrm{pH}$ varying between 5.6 and 6.5 and then reach a plateau (1310 $274 \pm 690 \mathrm{nM} ; \mathrm{n}=30$ ) for higher $\mathrm{pH}$ values. The $\mathrm{C}_{18} \mathrm{Cu}$ and $\mathrm{nonC}_{18} \mathrm{Cu}$ forms follow the same 275 trend than $\mathrm{TDCu}$ as expected from section 3.2. In the $\mathrm{pH}$ range of $5.6-6.5$, these fractions 276 increase from 1 to approximately $20 \mathrm{nM}$ and from 20 to approximately $1000 \mathrm{nM}$, 277 respectively. At $\mathrm{pH}>6.5$, their concentrations are relatively constant; i.e. $22 \pm 18 \mathrm{nM}$ and $2781250 \pm 680 \mathrm{nM}$, respectively. It is worth noting that the various copper fractions in the 279 hydrothermal fluid-richest sampled waters that were collected in a diffuse venting area (boxed 280 area in Figure 4) show higher levels than those observed at $\mathrm{pH} 5.6$ and collected within a 281 mussel clumps. 
In this part of the mixing zone, copper does not follow a conservative behaviour since it does

283 not show any negative correlation with $\mathrm{pH}$. Theoretical copper concentrations following a 284 simple dilution process were estimated using the data published by Charlou et al. (2000). Our data fall well above this theoretical mixing line for $\mathrm{pH}>6$, and are close or below this line for $\mathrm{pH}<6$ (Figure 4, dotted line).

287 In order to explain the peculiar behaviour of copper in this part of the mixing zone, the 288 fluctuations of dissolved oxygen $\left(\mathrm{O}_{2}\right)$ and total sulphide $(\Sigma \mathrm{S})$ in the studied area are also 289 presented (Figure 5 and 6). Dissolved oxygen was measured in situ with an Aanderaa optode moored in a neighbouring mussel clump. The results obtained show an expected decrease in oxygen concentration when increasing the hydrothermal input of reduced species. Total 292 sulphide was measured in situ at the 12 sampling points with the chemical analyzer 293 CHEMINI. The total sulphide vs. $\mathrm{pH}$ curve presents an inflexion point between $\mathrm{pH} 6.5$ and 7. The data clearly highlight the presence of a transition area at a $\mathrm{pH}$ around 6.7 between high sulphide/low oxygen waters and low sulphide/high oxygen waters. It can be seen that the lowest $\mathrm{Cu}$ concentrations measured at $\mathrm{pH}<6$ (Figure 4) correspond to high sulphide/low oxygen area. In this acidic part of the mixing zone, the copper concentration might be 298 controlled by precipitation with sulphide. As a matter of fact, James and Elderfield (1996) observed in the Snake pit vent field (MAR) that only $43 \%$ of copper was present in the dissolved fraction $(<0.4 \mu \mathrm{M})$. Copper occurs mainly as sulphides (such as chalcopyrite) that

301 form large sized grains and settle rapidly in the near field region (Trocine and Trefy, 1988; 302 Feely et al., 1994).

303 For $\mathrm{pH}>6$, the dissolved $\mathrm{Cu}$ concentrations follow a trend opposite to a conservative 304 behaviour: TDCu concentrations increase to reach a plateau at $\mathrm{pH}$ around 6.5. In the same $\mathrm{pH}$ 305 range, total sulphide levels are characterized by a sharp drop from 40 to ca. $10 \mu \mathrm{M}$. In the pH 306 range $6-6.5$, the copper enrichment observed could be related to the dissolution of settled 
copper sulphide particles in the presence of dissolved oxygen. The speciation of dissolved copper obtained in this study supports this hypothesis as most of the dissolved copper (> $96 \%$ ) is present under inorganic or hydrophilic organic complexes. Such an oxidative redissolution (oxic alteration) phenomenon has already been advanced to explain the

311 variations of dissolved copper in hydrothermal fluids during the oxidation of chalcopyrite by 312 seawater or diluted fluids (Metz and Trefry, 2000). In hydrothermal sediments from the EPR,

$313 \mathrm{Cu}$ is associated to $\mathrm{Fe}$ oxyhydroxides that can undergo dissolution under oxic conditions and 314 finally precipitate as goethite (Dunk and Mills, 2006). In the sediments of the TAG 315 hydrothermal field (26N, MAR), Severmann et al. (2006) reported elevated dissolved $\mathrm{Cu}$ 316 concentrations $(<0.2 \mu \mathrm{m})$ that might be caused by reaction between hydrothermal minerals 317 with oxygenated seawater within the suboxic/oxic area and producing a remobilization of $\mathrm{Cu}$. 318 Oxidative redissolution processes were also observed in other marine systems. For example, 319 Paucot and Wollast (1997) reported in the Scheldt estuary a removal of dissolved $\mathrm{Cu}(<0.45$ $320 \mu \mathrm{m})$ at low salinities due to sulphide precipitation in the anoxic part of the system. At higher 321 salinities and higher oxygen content, an increase of the dissolved fraction occurred as the 322 result of the redissolution of sulphide in oxic conditions.

323 For $\mathrm{pH}$ values higher than 7.5, one should expect in our system a strong decrease of dissolved 324 copper to reach the typical concentrations values of deep seawater (i.e. in the range 1-3 nM). In Figure 7, we propose a conceptual model forecasting the copper behaviour over the entire 326 hydrothermal fluid-seawater mixing zone. Three major phenomenon should be considered: (i) 327 the precipitation of copper with hydrogen sulphide in the anoxic area close to the vent orifice 328 at $\mathrm{pH}<6$; (ii) the oxidative redissolution of accumulated copper sulphides particles to form 329 inorganic and hydrophilic organic complexes with increasing oxygen concentrations for $\mathrm{pH}$ 330 between 6 and 7.5 and (iii) the dilution of high metal content waters with low $\mathrm{Cu}$ seawater. 
333 The observed remobilisation of dissolved copper in the part of the mixing zone that 334 corresponds to the preferred habitat of Bathymodiolus azoricus faunal assemblages can have 335 an important biological significance. This mytilid mussel is the dominant "engineering" 336 species colonizing the Tour Eiffel edifice (Desbruyères et al., 2001). This species hosts a dual 337 symbiotic population in its gills composed of methanotroph and sulfoxidant microorganisms 338 (Fiala-Medioni et al., 2002; Duperron et al., 2006). The morphology of its intestine suggests 339 also a residual dependence on filter feeding (Fiala-Medioni et al., 2002). Metals like Fe, Zn 340 and $\mathrm{Cu}$ are essential for live organisms but may become toxic if present in excess. 341 Bioaccumulation in B. azoricus from the MAR occurs mainly in the gills that correspond to

342 the main interface between the organism and its environment and also in the digestive gland 343 (Cosson et al., 2008). Furthermore, metal bioaccumulation appears to be related to the 344 specificity of each vent field and reflects partly the chemical composition of the hydrothermal 345 fluid (Cosson et al., 2008). Even though the main bioaccumulation pathway of metals in 346 bivalves comes from their trophic uptake (Wang, 2002; Wang and Rainbow, 2005), it was 347 shown that they can directly intake the metals from the solute phase through permeable 348 surfaces including the gills (Marsden and Rainbow, 2004). This pathway will be strongly 349 influenced by the speciation of dissolved metals, including the hydrophilic / hydrophobic 350 properties of metallic complexes. Metals in solution may be taken up across permeable 351 membranes via different transport routes. A metal ion can either bind with a carrier protein 352 that mediate the transport through the membrane or it can cross the membrane using ionic 353 channels formed by a protein with a hydrophilic core. In addition, some hydrophobic 354 complexes can cross directly the bilayer lipidic cell membrane and can be released in the cytoplasm. Nevertheless, this entry route appears to be quite limited (Simkiss, 1998). In summary, the main intake processes of dissolved metals involve ionic channels and are 
directly linked to the concentration of labile metal species (Simkiss, 1998). Therefore, the presence of a secondary source of dissolved copper, associated with the accumulation of metal sulphide particles, could play a significant role in the distribution of fauna in the different habitats available at vents. Whether different hydrothermal fauna have different tolerance and/or adaptation to deal with copper concentrations remains to be investigated.

\section{Conclusion}

364 In this study focused on the Tour Eiffel edifice (Lucky Strike vent field, MAR), levels of total dissolved copper range from $0.03 \mu \mathrm{M}$ to $5.15 \mu \mathrm{M}$. These values are much higher than the ones reported for deep-sea oceanic waters but are in accordance with the ones previously

367 obtained in this area. Our data from speciation measurements show, for the first time, that the hydrophobic organic fraction of copper $\left(\mathrm{C}_{18} \mathrm{Cu}\right)$ is very low $(2 \pm 1 \%)$ in the hydrothermal fluid-seawater mixing zone. On the other hand, copper is found mainly as inorganic and hydrophilic organic complexes $\left(\right.$ nonC $\left._{18} \mathrm{Cu}\right)$. This result is especially interesting because this

371 latter fraction is liable to be more bioavailable than the former one. The distribution of copper along the $\mathrm{pH}$ gradient shows the same pattern of evolution for each fraction. These fractions highly increase from $\mathrm{pH} 5.6$ to $\mathrm{pH} 6.5$, then remain relatively constant at $\mathrm{pH}>6.5$. Oxygen and sulphides data demonstrate that the copper anomaly at $\mathrm{pH} 6.5$ is found in the transition area between suboxic and oxic waters. Thus, the increase of dissolved copper should correspond to the oxidative redissolution of copper sulphide particles formed in the vicinity of

377 the fluid exit. Moreover, our data indicate that the inorganic and hydrophilic organic fraction 378 is the one to be mainly affected by this oxidative redissolution mechanism.

379 Further work will be done on the whole mixing zone from the hot or diffuse emission to the 380 seawater pole to check the proposed behaviour. In addition, the data acquired during this 
study will be used to look at the relationship between chemical gradients and species

distribution within Bathymodiolus azoricus mussel assemblages,

Acknowledgements

We would like to thank Captain Philippe Guillemet of the R/V "Pourquoi pas?" and his crew for their never-failing collaboration in the success of the MoMARETO cruise. We also acknowledge the Victor 6000 ROV pilots for their patience and constant support. This work was done with the financial support of the European Union EXOCET/D project (FP6-GOCE-

CT-2003-505342), the ANR Deep Oases (ANR06 BDV005) and the GDR ECCHIS.

\section{References}

392

Al-Farawati R, van den Berg CMG. Metal-sulfide complexation in seawater. Marine Chemistry 1999; 63: 331.

Bebianno MJ, Company R, Serafim A, Camus L, Cosson RP, Fiala-Médoni A. Antioxidant systems and lipid peroxidation in Bathymodiolus azoricus from Mid-Atlantic Ridge hydrothermal vent fields. Aquatic Toxicology 2005; 75: 354.

Bruland KW, Franks RP. Mn, Ni, Cu, Zn and $\mathrm{Cd}$ in the Western North Atlantic. In: NATO Conference series editor. Trace metals in seawater. 9. Plenum Press, NY, 1983, pp. 395.

Charlou JL, Donval JP, Douville E, Jean-Baptiste P, Radford-Knoery J, Fouquet Y, Dapoigny A, Stievenard M. Compared geochemical signatures and the evolution of Menez Gwen $\left(37^{\circ} 50^{\prime} \mathrm{N}\right)$ and Lucky Strike $\left(37^{\circ} 17^{\prime} \mathrm{N}\right)$ hydrothermal fluids, south of the Azores Triple Junction on the Mid-Atlantic Ridge. Chemical Geology 2000; 171: 49.

Childress JJ, Fisher CR. The biology of hydrothermal vent animals: physiology, biochemistry and autotrophic symbioses. In: Barnes M, A.D. Ansell, Gibson RN, editors. Oceanography and Marine Biology Annual Review. 30. UCL press, 1992, pp. 337-441.

Cosson RP, Vivier JP. Interactions of metallic elements and organisms within hydrothermal vents. Cahiers de Biologie Marine 1997; 38: 43-50.

Cosson RP, Thiébaut É, Company R, Castrec-Rouelle M, Colaço A, Martins I, Sarradin P-M, Bebianno MJ. Spatial variation of metal bioaccumulation in the hydrothermal vent mussel Bathymodiolus azoricus. Marine Environmental Research 2008; 65: 405. 
Desbruyères D, Chevaldonné P, Alayse AM, Jollivet D, Lallier FH, Jouin-Toulmond C, Zal F, Sarradin PM, Cosson R, Caprais JC, Arndt C, O'Brien J, Guezennec J, Hourdez S, Riso R, Gaill F, Laubier L, Toulmond A. Biology and ecology of the "Pompeii worm" (Alvinella pompejana Desbruyères and Laubier), a normal dweller of an extreme deepsea environment: A synthesis of current knowledge and recent developments. Deep Sea Research Part II: Topical Studies in Oceanography 1998; 45: 383.

Desbruyères D, Biscoito M, Caprais JC, Colaço A, Comtet T, Crassous P, Fouquet Y, Khripounoff A, Le Bris N, Olu K, Riso R, Sarradin PM, Segonzac M, Vangriesheim A. Variations in deep-sea hydrothermal vent communities on the Mid-Atlantic Ridge near the Azores plateau. Deep Sea Research Part I: Oceanographic Research Papers 2001; 48: 1325 .

Di Meo-Savoie CA, Luther GW, Cary SC. Physicochemical characterization of the microhabitat of the epibionts associated with Alvinella pompejana, a hydrothermal vent annelid. Geochimica et Cosmochimica Acta 2004; 68: 2055-2066.

Donat JR, Statham PJ, Bruland KW. An evaluation of a C-18 solid phase extraction technique for isolating metal-organic complexes from central North Pacific Ocean waters. Marine Chemistry 1986; 18: 85.

Donat JR, Lao KA, Bruland KW. Speciation of dissolved copper and nickel in South San Francisco Bay: a multi method approach. Analytica Chimica Acta 1994; 284: 547-571.

Donat JR, Bruland KW. Trace metals in the oceans. In: Steinnes E, Salbu B, editors. Trace elements in natural waters. CRC press, Boca Raton, FLA, USA, 1995, pp. 302.

Douville E, Charlou JL, Oelkers EH, Bienvenu P, Jove Colon CF, Donval JP, Fouquet Y, Prieur D, Appriou P. The Rainbow vent fluids $\left(36^{\circ} 14^{\prime} \mathrm{N}, \mathrm{MAR}\right)$ : the influence of ultramafic rocks and phase separation on trace metal content in Mid-Atlantic Ridge hydrothermal fluids. Chemical Geology 2002; 184: 37.

Dunk RM, Mills RA. The impact of oxic alteration on plume-derived transition metals in ridge flank sediments from the East Pacific Rise. Marine Geology 2006; 229: 133.

Duperron S, Bergin C, Zielinski F, Blazejak A, Pernthaler A, McKiness ZP, DeChaine E, Cavanaugh CM, Dubilier N. A dual symbiosis shared by two mussel species, Bathymodiolus azoricus and Bathymodiolus puteoserpentis (Bivalvia: Mytilidae), from hydrothermal vents along the northern Mid-Atlantic Ridge. Environmental Microbiology 2006; 8: 1441-1447. 
El Sayed MA, Aminot A. $C_{18}$ Sep-Pak Extractable Dissolved Organic Copper Related to Hydrochemistry in the North-west Mediterranean. Estuarine, Coastal and Shelf Science 2000; 50: 835 .

Elbaz-Poulichet F, Cauwet G, Guan DM, Faguet D, Barlow R, Mantoura RFC. C 18 Sep-Pak extractable trace metals in waters from the Gulf of Lions. Marine Chemistry 1994; 46: 67.

Feely RA, Geiselman TL, Baker ET, Massoth GJ, Hammond SR. Distribution and composition of hydrothermal plumes particles from the ASHES vent field at axial volcano, Juan de Fuca ridge. Journal of Geophysical Research 1990; 95: 12855-12873.

Feely RA, Gendron JF, Baker ET, Lebon GT. Hydrothermal plumes along the East Pacific Rise, $8^{\circ} 40^{\prime}$ to $11^{\circ} 50^{\prime} \mathrm{N}$ : Particle distribution and composition. Earth and Planetary Science Letters 1994; 128: 19.

Fiala-Medioni A, McKiness ZP, Dando P, Boulegue J, Mariotti A, Alayse-Danet AM, Robinson JJ, Cavanaugh CM. Ultrastructural, biochemical, and immunological characterization of two populations of the mytilid mussel Bathymodiolus azoricus from the Mid-Atlantic Ridge: evidence for a dual symbiosis. Marine Biology 2002; 141: 1035-1043.

Fouquet Y, Ondreas H, Charlou JL, Donval JP, Radford-Knoery J, Costa I, Lourenco N, Tivey MK. Atlantic lava lakes and hot vents. Nature 1995; 377: 201.

Geret F, Rousse N, Riso R, Sarradin PM, Cosson R. Metal compartmentalization and metallothionein isoforms in mussels from the Mid-Atlantic Ridge; preliminary approach to the fluid-organism relationship. Cahiers de Biologie Marine 1998; 39: 291-293.

Geret F, Riso R, Sarradin PM, Caprais JC, Cosson R. Metal bioaccumulation and storage forms in the shrimp, Rimicaris exoculata, from the Rainbow hydrothermal field (Mid Atlantic Ridge); preliminary approach to the fluid-organism relationship. Cahiers de Biologie Marine 2002; 43: 43-52.

Hanson AK, Quinn JG. The distribution of dissolved and organically complexed copper and nickel in the middle Atlantic Bight. Canadian Journal of Fisheries and Aquatic Sciences 1983; 40: 151-161.

Holm NG, Charlou JL. Initial indications of abiotic formation of hydrocarbons in the Rainbow ultramafic hydrothermal system, Mid-Atlantic Ridge. Earth and Planetary Science Letters 2001; 191: 1.

James RH, Elderfield H. Dissolved and particulate trace metals in hydrothermal plumes at the Mid-Atlantic Ridge. Geophysical Research Letters 1996; 23: 3499-3502. 
Kadar E, Costa V, Martins I, Santos RS, Powell JJ. Enrichment in Trace Metals (Al, Mn, Co, $\mathrm{Cu}, \mathrm{Mo}, \mathrm{Cd}, \mathrm{Fe}, \mathrm{Zn}, \mathrm{Pb}$ and $\mathrm{Hg}$ ) of Macro-Invertebrate Habitats at Hydrothermal Vents Along the Mid-Atlantic Ridge. Hydrobiologia 2005; 548: 191.

Le Bris N, Govenar B, Le Gall C, Fisher CR. Variability of physico-chemical conditions in 950'N EPR diffuse flow vent habitats. Marine Chemistry 2006; 98: 167.

Le Gall AC, Statham PJ, Morley NH, Hydes DJ, Hunt CH. Processes influencing distributions and concentrations of $\mathrm{Cd}, \mathrm{Cu}, \mathrm{Mn}$ and $\mathrm{Ni}$ at the North West European shelf break. Marine Chemistry 1999; 68: 97-115.

Limén H, Levesque C, Kim Juniper S. POM in macro-/meiofaunal food webs associated with three flow regimes at deep-sea hydrothermal vents on Axial Volcano, Juan de Fuca Ridge. Marine Biology 2007; 153: 129.

Loaëc M, Olier R, Guezennec J. Chelating properties of bacterial exopolysaccharides from deep-sea hydrothermal vents. Carbohydrate Polymers 1998; 35: 65.

Luther GW, Rozan TF, Taillefert M, Nuzzio DB, Di Meo C, Shank TM, Lutz RA, Cary SC. Chemical speciation drives hydrothermal vent ecology. Nature 2001; 410: 813-816.

Marsden ID, Rainbow PS. Does the accumulation of trace metals in crustaceans affect their ecology- the amphipod example? Journal of Experimental Marine Biology and Ecology 2004; 300: 373.

Metz S, Trefry JH. Chemical and mineralogical influences on concentrations of trace metals in hydrothermal fluids. Geochimica et Cosmochimica Acta 2000; 64: 2267.

Mills GL, Quinn JG. Isolation of dissolved organic matter and copper-organic complexes from estuarine waters using reverse-phase liquid chromatography. Marine Chemistry 1981; 10: 93.

Nichols CAM, Guezennec J, Bowman JP. Bacterial Exopolysaccharides from Extreme Marine Environments with Special Consideration of the Southern Ocean, Sea Ice, and Deep-Sea Hydrothermal Vents: A Review. Marine Biotechnology 2005; 7: 253.

Paucot H, Wollast R. Transport and transformation of trace metals in the Scheldt estuary. Marine Chemistry 1997; 58: 229.

Paulson AJ, Curl HC, Gendron JF. Partitioning of $\mathrm{Cu}$ in estuarine waters, I. Partitioning in a poisoned system. Marine Chemistry 1994; 45: 67.

Riso RD, Le Corre P, Chaumery CJ. Rapid and simultaneous analysis of trace metals $(\mathrm{Cu}, \mathrm{Pb}$, and $\mathrm{Cd}$ ) in seawater by potentiometric stripping analysis. Analytica Chimica Acta 1997a; 351: 83-89. 
Riso RD, Monbet P, Le Corre P. Measurement of copper in sea-water by constant current stripping analysis (CCSA) with a rotating gold disk electrode. The Analyst 1997b; 122: 1593-1596.

Ruelas-Inzunza J, Soto LA, Paez-Osuna F. Heavy-metal accumulation in the hydrothermal vent clam Vesicomya gigas from Guaymas basin, Gulf of California. Deep Sea Research I 2003; 50: 757-761.

Ruelas-Inzunza J, Paez-Osuna F, Soto LA. Bioaccumulation of $\mathrm{Cd}, \mathrm{Co}, \mathrm{Cr}, \mathrm{Cu}, \mathrm{Fe}, \mathrm{Hg}, \mathrm{Mn}$, $\mathrm{Ni}, \mathrm{Pb}$ and $\mathrm{Zn}$ in trophosome and vestimentum of the tube worm Riftia pachyptila from Guaymas basin, Gulf of California. Deep Sea Research Part I: Oceanographic Research Papers 2005; 52: 1319-1323.

Saager PM, de Baar HJW, de Jong JTM, Nolting RF, Schijf J. Hydrography and local sources of dissolved trace metals $\mathrm{Mn}, \mathrm{Ni}, \mathrm{Cu}$, and $\mathrm{Cd}$ in the northeast Atlantic Ocean. Marine Chemistry 1997; 57: 195.

Sander SG, Koschinsky A, Massoth G, Stott M, Hunter KA. Organic complexation of copper in deep-sea hydrothermal vent systems. Environmental Chemistry 2007; 4: 81-89.

Sarradin PM, Caprais JC, Riso R, Kerouel R, Aminot A. Chemical environment of the hydrothermal mussel communities in the Lucky Strike and Menez Gwen vent fields, MAR. Cahiers de Biologie Marine 1999; 40: 93-104.

Sarradin P-M, Sarrazin J, Allais AG, Almeida D, Brandou V, Boetius A, Buffier E, Coiras E, Colaço A, Cormack A, Dentrecolas S, Desbruyères D, Dorval P, du Buf H, Dupont J, Godfroy A, Gouillou M, Gronemann J, Hamel G, Hamon M, Hoge U, Lane D, Le Gall C, Leroux D, Legrand J, Léon P, Lévèque JP, Masson M, Olu K, Pascoal A, Sauter E, Sanfilippo L, Savino E, Sebastião L, Serrão Santos R, Shillito B, Siméoni P, Schultz A, Sudreau JP, Taylor P, Vuillemin R, Waldmann C, Wenzhöfer F, Zal F. EXtreme ecosystem studies in the deep OCEan: Technological Developments. InterRidge News 2007; 16: 17-21.

Sarradin P-M, Lannuzel D, Waeles M, Crassous P, Le Bris N, Caprais JC, Fouquet Y, Fabri $\mathrm{MC}$, Riso R. Dissolved and particulate metals ( $\mathrm{Fe}, \mathrm{Zn}, \mathrm{Cu}, \mathrm{Cd}, \mathrm{Pb}$ ) in two habitats from an active hydrothermal field on the EPR at $13^{\circ} \mathrm{N}$. Science of The Total Environment 2008; 392: 119-129.

Sarrazin J, Sarradin PM, and the cruise participants. MoMARETO: a cruise dedicated to the spatio-temporal dynamics and the adaptations of hydrothermal vent fauna on the MidAtlantic Ridge. InterRidge News 2006a; 15: 24-33. 
Sarrazin J, Walter C, Sarradin PM, Brind'amour A, Desbruyères D, Briand P, Fabri MC, Van Gaever S, Van Reusel A, Bachraty C, Thiébaut E. Community structure and temperature dynamics within a mussel assemblage on the Southern East Pacific Rise. Cahier de Biologie Marine 2006b; 47: 483-490.

Severmann S, Mills RA, Palmer MR, Telling JP, Cragg B, John Parkes R. The role of prokaryotes in subsurface weathering of hydrothermal sediments: A combined geochemical and microbiological investigation. Geochimica et Cosmochimica Acta 2006; 70: 1677.

Shillito B, Hamel G, Duchi C, Cottin D, Sarrazin J, Sarradin PM, Ravaux J, Gaill F. Live capture of megafauna from $2300 \mathrm{~m}$ depth, using a newly designed Pressurized Recovery Device. Deep Sea Research Part I: Oceanographic Research Papers; In Press.

Simkiss K. Mechanism of metal uptake. In: Langston WJ, Bebianno MJ, editors. Metal metabolism in aquatic environments. Chapman \& Hall Ltd, 1998, pp. 1-15.

Tengberg A, Hovdenes J, Andersson HJ, Brocandel O, Diaz R, Hebert D, Arnerich T, Huber C, Körtzinger A, Khripounoff A, Rey F, Rönning C, Schimanski J, Sommer S, Stangelmayer A. Evaluation of a lifetime-based optode to measure oxygen in aquatic systems. Limnology and Oceanography: Methods 2006; 4: 7-17.

Trefry JH, Trocine RP. Iron and copper enrichment of suspended particles in dispersed hydrothermal plumes along the Mid Atlantic Ridge. Geophysical Research Letters 1985; 12: 506-509.

Trocine RP, Trefy JH. Distribution and chemistry of suspended particles from an active hydrothermal vent site on the Mid-Atlantic Ridge at $26^{\circ} \mathrm{N}$. Earth and Planetary Science Letters 1988; 88: 1-15.

Urcuyo IA, Massoth GJ, Julian D, Fisher CR. Habitat, growth and physiological ecology of a basaltic community of Ridgeia piscesae from the Juan de Fuca Ridge. Deep Sea Research Part I: Oceanographic Research Papers 2003; 50: 763.

Von Damm KL, Bray AM, Buttermore LG, Oosting SE. The geochemical controls on vent fluids from the Lucky Strike vent field, Mid-Atlantic Ridge. Earth and Planetary Science Letters 1998; 160: 521.

Vuillemin R, Le Roux D, Dorval P, Hamon M, Sudreau JP, Le Gall C, Sarradin PM. CHEMINI: CHEmical MINIaturised analyzer: A new generation of in situ chemical analyzers for marine applications. Instrumentation viewpoint 2007; 6: 9. 
Vuillemin R, Le Roux D, Dorval P, Bucas K, Sudreau JP, Hamon M, Le Gall C, Sarradin PM. CHEMINI: a new in situ CHEmical MINIaturized analyzer. Deep Sea Research part I Instruments and methods submitted 06/2008.

Waeles M, Riso RD, Maguer J-F, Le Corre P. Distribution and chemical speciation of dissolved cadmium and copper in the Loire estuary and North Biscay continental shelf, France. Estuarine, Coastal and Shelf Science 2004; 59: 49.

581 Waeles M, Riso RD, Le Corre P. Seasonal variations of dissolved and particulate copper species in estuarine waters. Estuarine, Coastal and Shelf Science 2005; 62: 313.

Wang W-X. Interactions of trace metals and different marine food chains. Marine Ecology Progress Series 2002; 243: 295-309.

Wang W-X, Rainbow PS. Influence of metal exposure history on trace metal uptake and accumulation by marine invertebrates. Ecotoxicology and Environmental Safety 2005; 61: 145 .

Yoon Y-Y, Martin J-M, Cotté MH. Dissolved trace metals in the Western Mediterranean Sea: total concentration and fraction isolated by $\mathrm{C}_{18}$ Sep-Pak technique. Marine Chemistry 1999; 66: 129. 


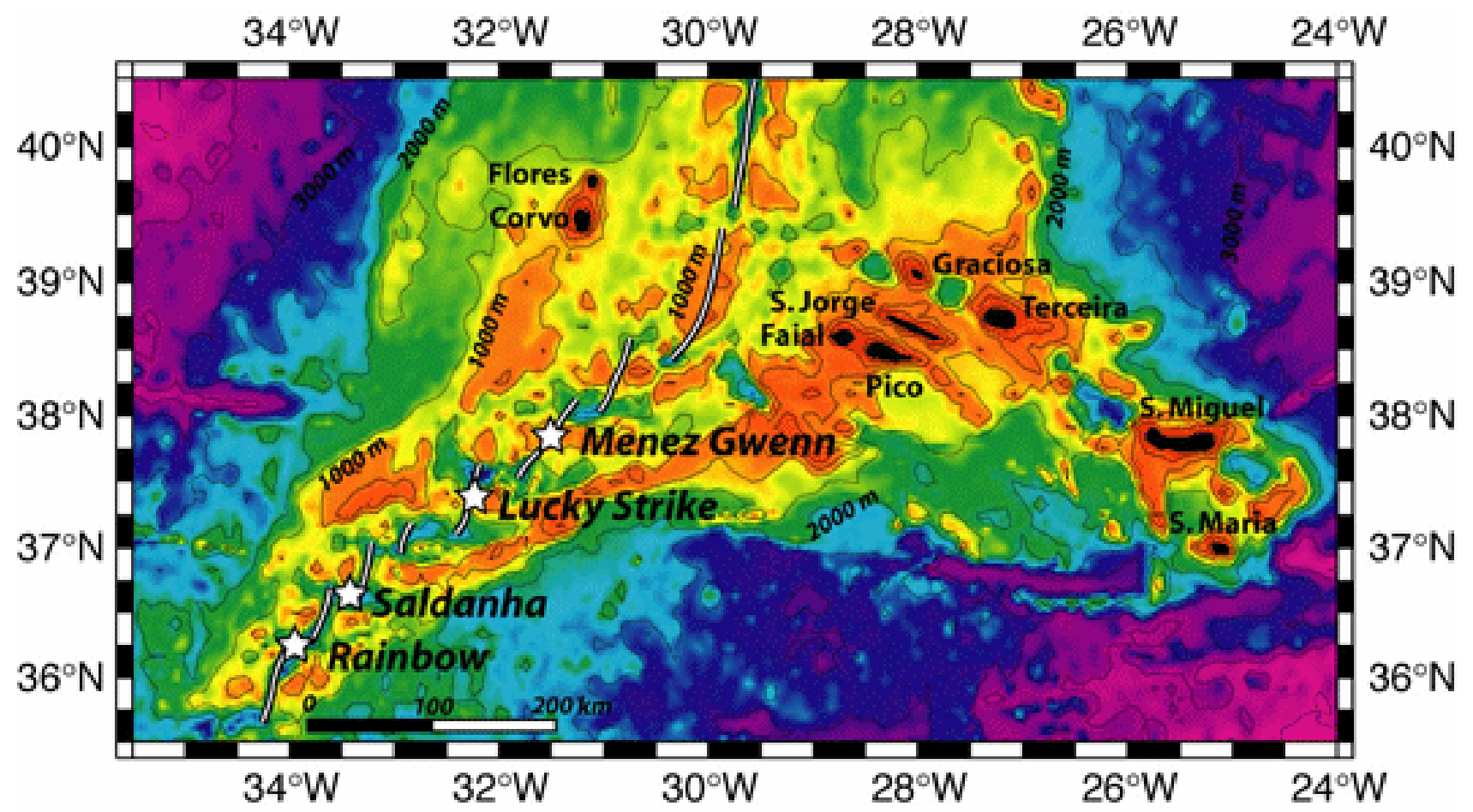

Fig. 1- Simplified bathymetric map of the Mid-A tlantic Ridge near the Azores (seafloor depths in meters), showing the location of the four main hydrothermal vent fields. (http://www.momarfr.org/) 


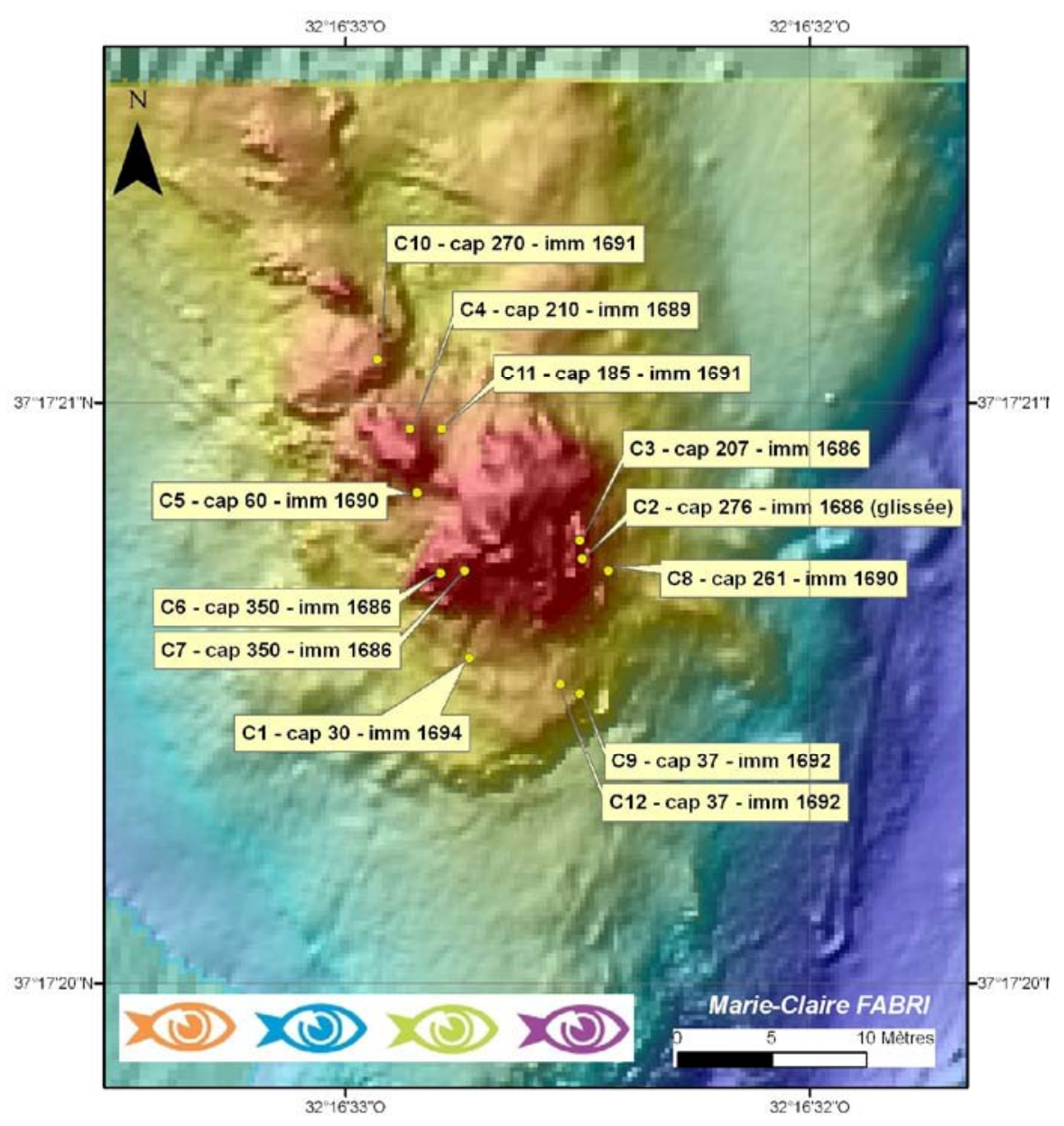

Fig. 2- Bathymetric map of the Tour Eiffel active edifice and location of the 12 sampling stations $\mathrm{C} 1$ to C12 (Sarrazin et al., 2006). 


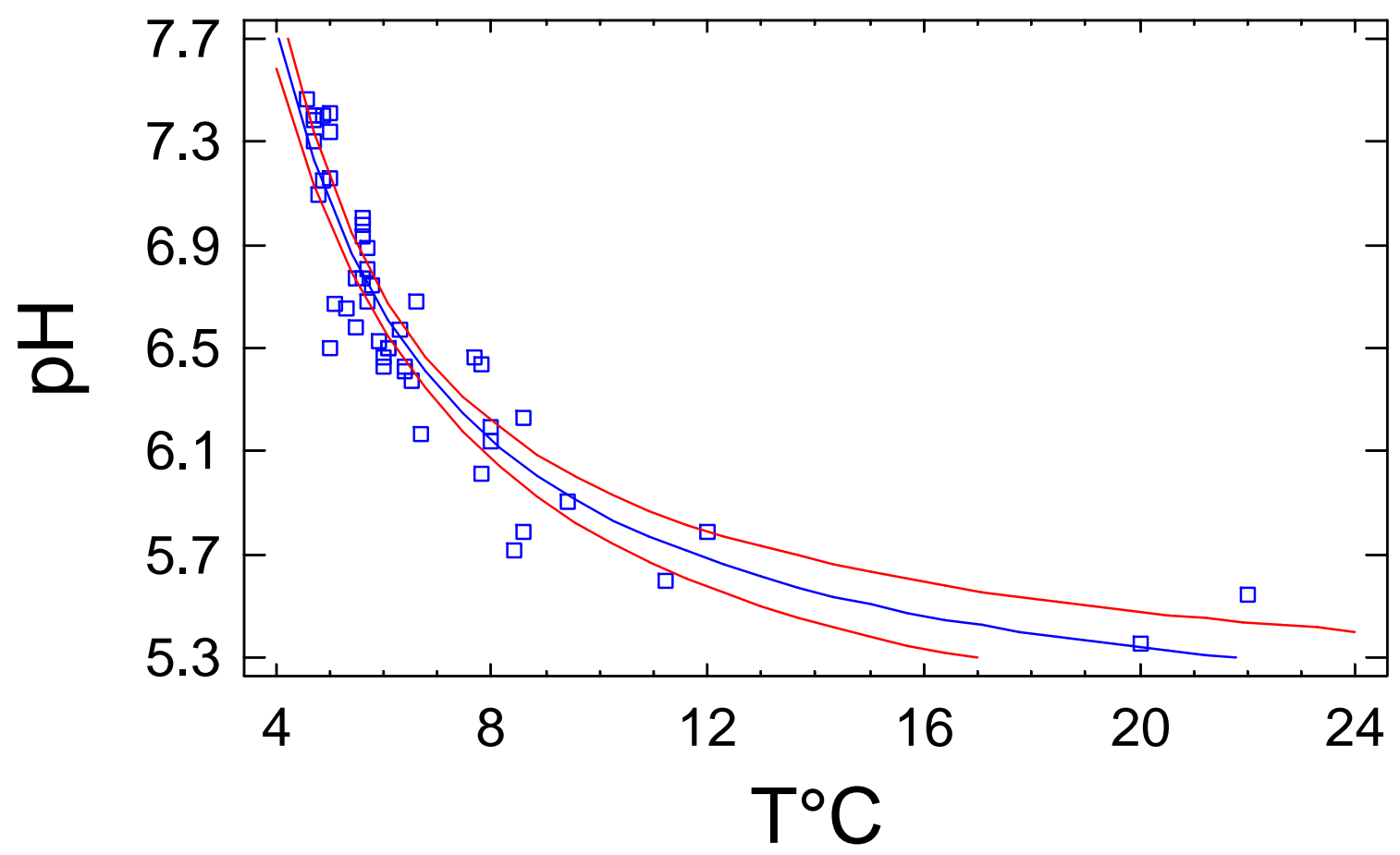

Fig. 3- Temperature/pH relationship obtained in the cold part of the mixing zone. $\mathrm{pH}=\exp ^{(1.582+1.857 / T)}$, $R^{2}=86.6 \%, n=42$. The external lines represent the confidence interval at 95\% (Statgraphics Plus). 


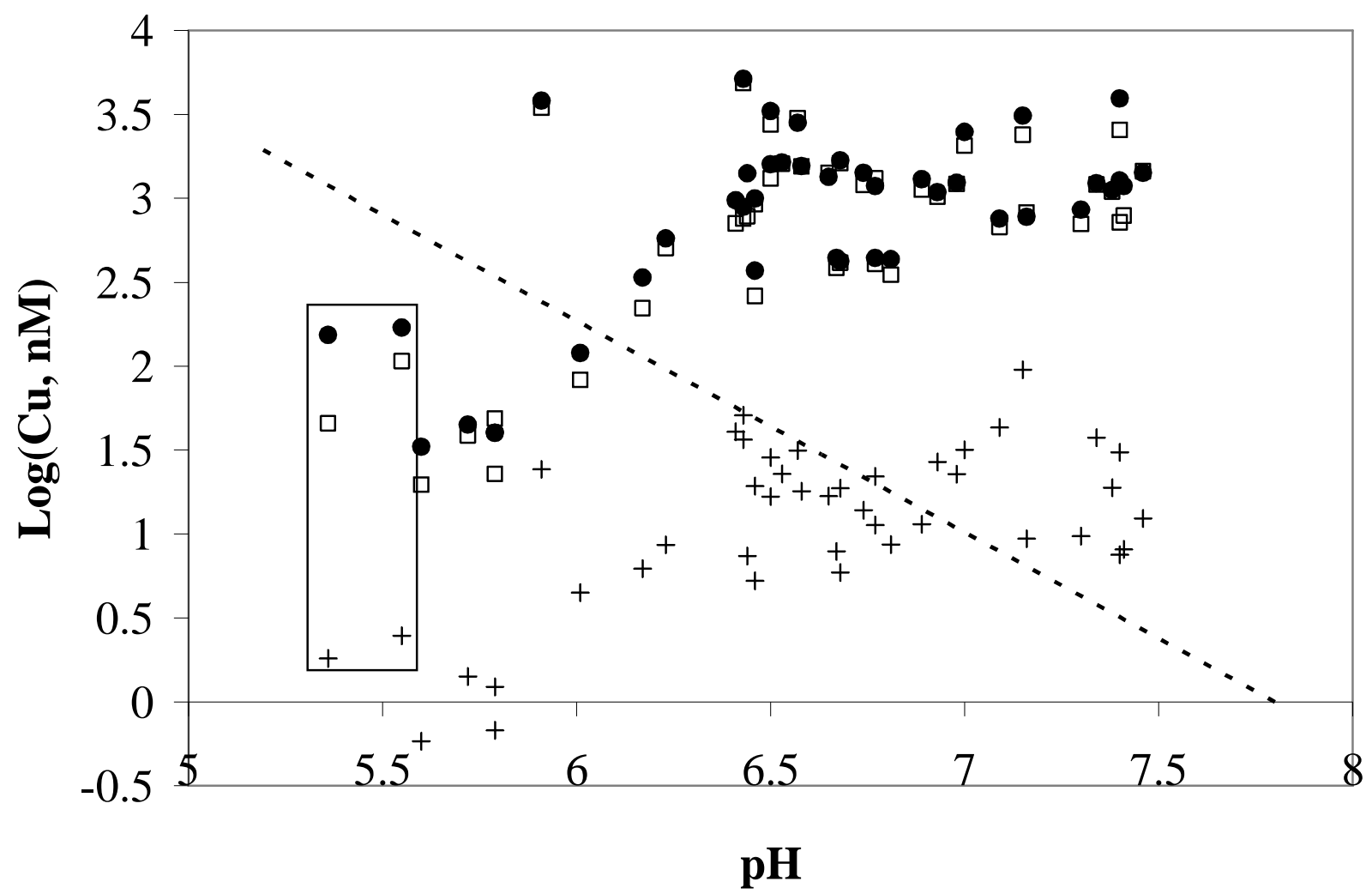

Fig. 4- Distribution of copper concentrations $[\mathrm{Log}(\mathrm{Cu}, \mathrm{nM})]$ vs pH. TDCu (•), $\mathrm{C}_{18} \mathrm{Cu}(+)$ nonC $_{18} \mathrm{Cu}$ ( $\square)$. The boxed area indicates the samples with the lowest $\mathrm{pH} /$ highest temperature $\left(\sim 22^{\circ} \mathrm{C}\right)$ collected in a diffuse venting area. The dotted line represents a theoretical dilution of hydrothermal copper [pH $=4.3, \mathrm{Cu}=26000 \mathrm{nM},($ Charlou et al., 2000)] by seaw ater, $\mathrm{pH} 7.8, \mathrm{Cu}=1 \mathrm{nM}$. 


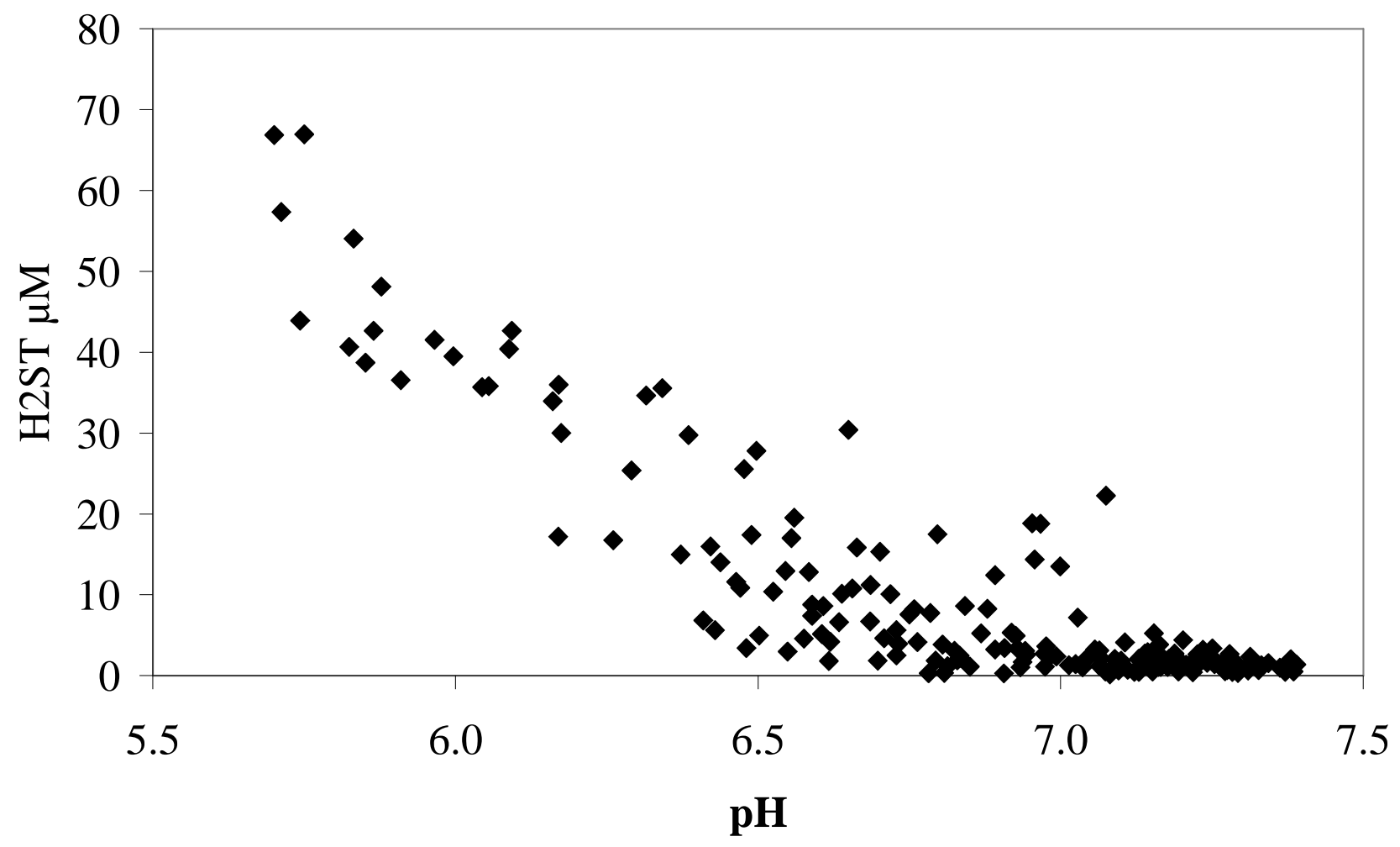

Fig. 5- Concentration of total sulphide measured in situ with the CHEMINI chemical analyzer on the 12 sampling points $\left(T=4.5\right.$ to $\left.11.7^{\circ} \mathrm{C}, \mathrm{n}=189\right)$. 


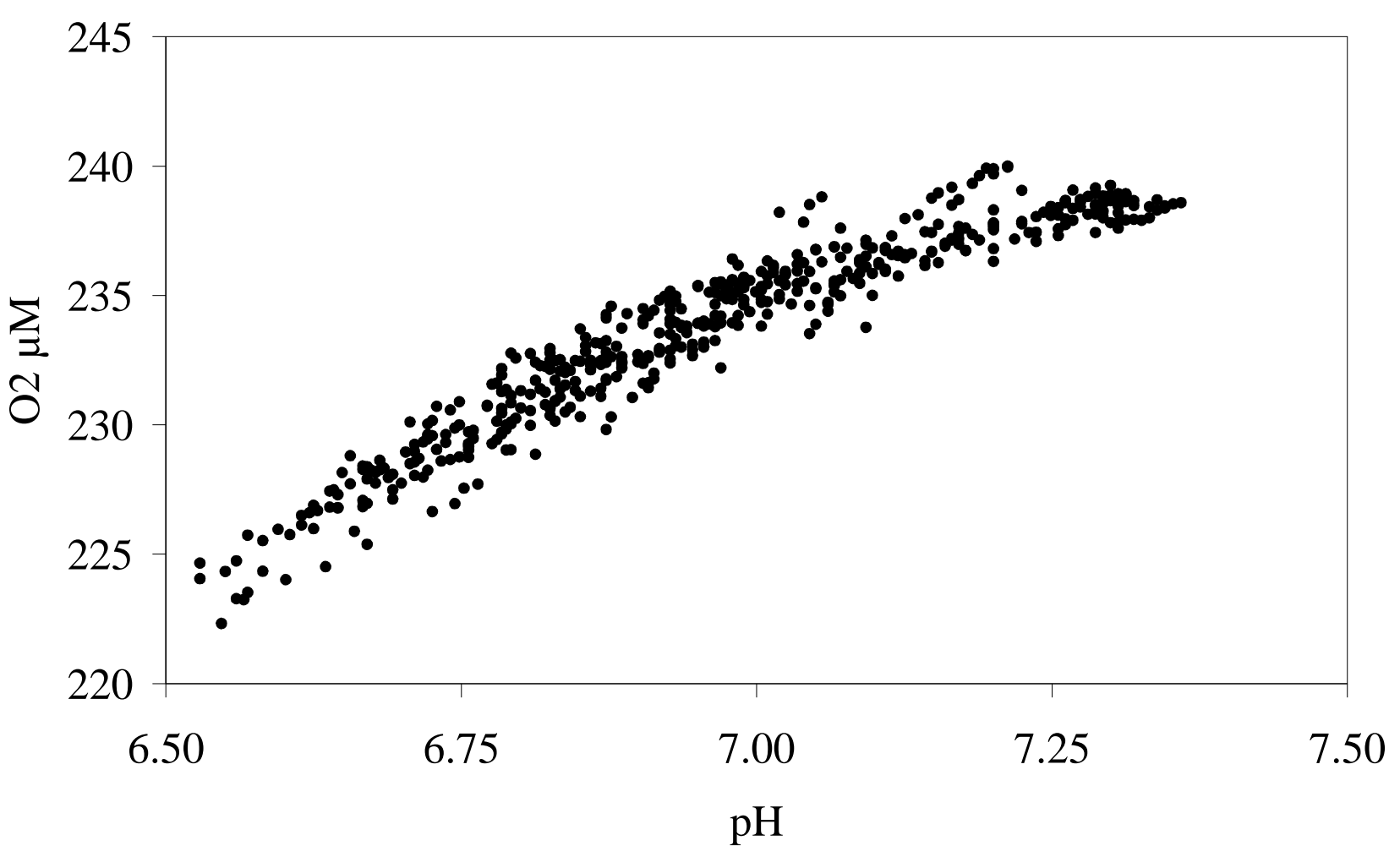

Fig. 6- Concentration of dissolved oxygen measured in situ by an A anderaa optode in a neighbouring mussel clump during 4 hours $\left(2 \mathrm{mes} / \mathrm{min}, \mathrm{n}=480, \mathrm{~T}=4.5\right.$ to $6.3^{\circ} \mathrm{C}$ ). 


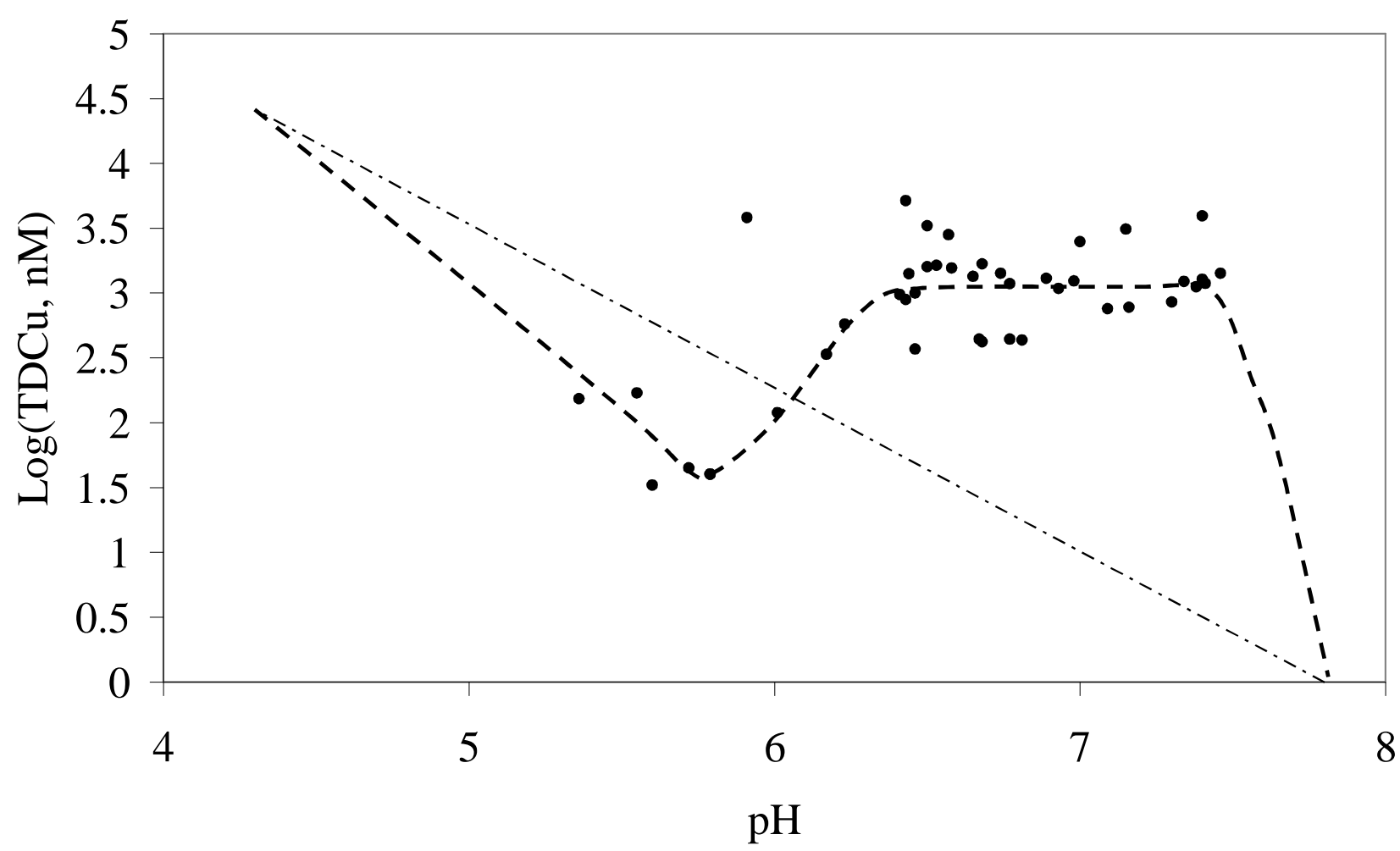

Fig. 7- Proposed schematic behaviour of dissolved copper in the hydrothermal fluid-seawater mixing zone. The dotted straight line represents the theoretical dilution of hydrothermal copper $(\mathrm{pH}=4.3, \mathrm{~T}=$ $325, \mathrm{Cu}=26000 \mathrm{nM})$ by seawater. 


\section{TABLES}

\begin{tabular}{ccc} 
& \multicolumn{2}{c}{ Cu (nM) } \\
& Certified value & M easured value \\
\hline NASS-5 & $4.7 \pm 0.7$ & $4.4 \pm 0.2$ \\
CASS-3 & $8.1 \pm 1.0$ & $7.6 \pm 0.5$ \\
SLEW-2 & $25.7 \pm 1.7$ & $27.2 \pm 1.4$ \\
\hline
\end{tabular}

Table 1- A nalysis of $\mathrm{Cu}$ in certified seawater samples: NASS-5 oceanic seawater, CASS-3 coastal seawater, SLEW -2 estuarine water. V alues are expressed as mean \pm confidence interval (95\%) 


\begin{tabular}{|c|c|c|c|c|}
\hline H ydrothermal fields & $\mathrm{Cu}(\mu \mathrm{M})$ & $\mathbf{T}^{\circ} \mathrm{C}$ & pH & R eferences \\
\hline$E P R, 9^{\circ} \mathrm{N}$ & $0.08-2.10 * * *$ & $13-176$ & $5.3-6.4$ & Di M eo-Savoie et al., 2004 \\
\hline $\mathrm{EPR}, 13^{\circ} \mathrm{N}$ & $1.38-3.27 *$ & - & $5.7-7.5$ & Desbruyères et al., 1998 \\
\hline $\mathrm{EPR}, 13^{\circ} \mathrm{N}$ & $0.18-1.6^{*}$ & $3.8-20$ & - & Sarradin et al., 2008 \\
\hline MAR, Rainbow & $0.14-3.20 *$ & $4.7-25$ & $6.3-7.5$ & Geret et al., 2002 \\
\hline M AR, LS, Tour Eiffel & $0.02-2.05^{*}$ & - & - & Geret et al., 1998 \\
\hline MAR, LS & $1.13 * *$ & 4.3 & 6.2 & K adar et al., 2005 \\
\hline MAR, LS, Tour E iffel & $0.03-5.15 * *$ & $4.6-22$ & $5.4-7.5$ & This study \\
\hline
\end{tabular}

Table 2- Concentrations of copper in various hydrothermal systems colonized by hydrothermal fauna. M A R: M id A tlantic Ridge; EPR: East Pacific Rise; LS: Lucky Strike vent field. * unfiltered samples, ** samples filtered on a $0.45 \mu \mathrm{m}$ filter. ${ }^{* * *}$ samples filtered and centrifugated. 
A ppendix $1: \mathrm{pH}$, temperature and total dissolved copper obtained in the 43 samples.

$\mathrm{pH}$ measurements were performed onboard using a $\mathrm{Metrohm}{ }^{\circledR} \mathrm{pH}$-meter with a combined $\mathrm{pH}$ electrode for sulphide rich medium. Sample temperatures were derived from the data recorded by the temperature probe associated with the sample inlet. Samples were filtered on board through a 0.45$\mu \mathrm{m}$-M illipore ${ }^{\circledR}$-HA TF filter. The separation and the quantification of the hydrophobic organic copper complexes $\left(\mathrm{C}_{18} \mathrm{Cu}\right)$, and the inorganic and hydrophilic organic complexes (non ${ }_{18} \mathrm{Cu}$ ) were performed on shore.

\begin{tabular}{|c|c|c|c|c|c|}
\hline Sample & $\mathrm{pH}$ & $\mathrm{T}^{\circ} \mathrm{C}$ & TDCu $(\mu \mathrm{M})$ & nonC $_{18} \mathrm{Cu}(\mu \mathrm{M})$ & $\mathrm{C}_{18} \mathrm{Cu}(\mu \mathrm{M})$ \\
\hline $296 \mathrm{~A} 2$ & 5.6 & 11.2 & 0.033 & 0.02 & 0.001 \\
\hline $300 \mathrm{E} 1$ & 5.72 & 8.4 & 0.045 & 0.04 & 0.001 \\
\hline 300 D3 & 5.79 & 8.6 & 0.040 & 0.05 & 0.001 \\
\hline $301 \mathrm{Cl}$ & 5.79 & 12 & 0.040 & 0.02 & 0.001 \\
\hline 300 D2 & 6.01 & 7.8 & 0.120 & 0.08 & 0.004 \\
\hline $296 \mathrm{~A} 1$ & 6.17 & 6.7 & 0.337 & 0.22 & 0.006 \\
\hline 297 A 1 & 6.23 & 8.6 & 0.576 & 0.51 & 0.009 \\
\hline 300 B2 & 6.41 & 6.4 & 0.976 & 0.71 & 0.041 \\
\hline 296 B 1 & 6.43 & 6 & 0.890 & 0.76 & 0.036 \\
\hline 296 B 2 & 6.43 & 6.4 & 5.151 & 4.85 & 0.051 \\
\hline $301 C 2$ & 6.44 & 7.8 & 1.410 & 0.78 & 0.007 \\
\hline 297 C1 & 6.46 & 7.7 & 1.00 & 0.92 & 0.019 \\
\hline 300 B 3 & 6.46 & 6 & 0.37 & 0.26 & 0.005 \\
\hline 297 B 2 & 6.5 & 5 & 3.31 & 2.76 & 0.029 \\
\hline $300 C 3$ & 6.5 & 6.1 & 1.60 & 1.31 & 0.017 \\
\hline $300 \mathrm{Cl}$ & 6.53 & 5.9 & 1.64 & 1.61 & 0.023 \\
\hline 301 B 2 & 6.57 & 6.3 & 2.82 & 3.00 & 0.031 \\
\hline $300 \mathrm{C2}$ & 6.58 & 5.5 & 1.56 & 1.55 & 0.018 \\
\hline 301 B 1 & 6.65 & 5.3 & 1.34 & 1.42 & 0.017 \\
\hline 296 A 3 & 6.67 & 5.11 & 0.44 & 0.39 & 0.008 \\
\hline 297 B 3 & 6.68 & 5.7 & 0.42 & 0.41 & 0.006 \\
\hline 301 B 3 & 6.68 & 6.6 & 1.68 & 1.62 & 0.019 \\
\hline 301 A 2 & 6.74 & 5.8 & 1.42 & 1.21 & 0.014 \\
\hline 300 D1 & 6.77 & 5.6 & 1.18 & 1.31 & 0.022 \\
\hline 300 B 1 & 6.77 & 5.5 & 0.44 & 0.41 & 0.011 \\
\hline $300 \mathrm{~A} 3$ & 6.81 & 5.7 & 0.43 & 0.35 & 0.009 \\
\hline 297 B 1 & 6.89 & 5.7 & 1.30 & 1.13 & 0.011 \\
\hline $300 \mathrm{~A} 1$ & 6.93 & 5.6 & 1.09 & 1.02 & 0.027 \\
\hline
\end{tabular}




\begin{tabular}{lcclll}
$300 \mathrm{~A} 2$ & 6.98 & 5.6 & 1.24 & 1.22 & 0.023 \\
$301 \mathrm{~A} 1$ & 7 & 5.6 & 2.49 & 2.06 & 0.032 \\
$297 \mathrm{E} 2$ & 7.09 & 4.8 & 0.76 & 0.67 & 0.043 \\
$297 \mathrm{C} 3$ & 7.15 & 4.9 & 3.11 & 2.40 & 0.095 \\
$301 \mathrm{~A} 3$ & 7.16 & 5 & 0.78 & 0.82 & 0.009 \\
$301 \mathrm{C} 3$ & 7.3 & 4.7 & 0.86 & 0.70 & 0.010 \\
$297 \mathrm{D} 2$ & 7.34 & 5 & 1.23 & 1.21 & 0.038 \\
$301 \mathrm{D} 1$ & 7.38 & 4.7 & 1.12 & 1.10 & 0.019 \\
$297 \mathrm{D} 1$ & 7.4 & 4.7 & 3.95 & 2.56 & 0.031 \\
$301 \mathrm{D} 2$ & 7.4 & 4.9 & 1.28 & 0.72 & 0.008 \\
$301 \mathrm{D} 3$ & 7.41 & 5 & 1.19 & 0.79 & 0.008 \\
$297 \mathrm{D} 3$ & 7.46 & 4.6 & 1.42 & 1.45 & 0.012 \\
$297 \mathrm{C} 2$ & 5.91 & 9.4 & 3.82 & 3.47 & 0.024 \\
$296 \mathrm{C} 1$ & 5.55 & 22 & 0.17 & 0.11 & 0.002 \\
296 B 3 & 5.36 & 20 & 0.15 & 0.05 & 0.002 \\
\hline
\end{tabular}

